\title{
Egzaminy potwierdzające kwalifikacje zawodowe
}

DOI: $10.47050 / 65591814.216-243$

Michał Sitek

W rozdziale podsumowano polskie doświadczenia wdrażania egzaminów zewnętrznych w kształceniu zawodowym. Wskazano główne motywacje i oczekiwania, które towarzyszyły wdrażaniu nowego systemu potwierdzania kwalifikacji, zasadnicze zmiany w systemie egzaminacyjnym wprowadzane w ostatnich kilkunastu latach oraz wyzwania, jakie stoją przed systemem egzaminacyjnym. Podkreślono związek egzaminów zawodowych z innymi elementami systemu kształcenia zawodowego, w tym przede wszystkim z systemem klasyfikacji zawodów szkolnych i podziałem zawodów na kwalifikacje. Główne wyzwania zidentyfikowane $w$ analizach wiążą się z trudnością pogodzenia różnych funkcji egzaminów, które mają z jednej strony dawać informację o jakości kształcenia na różnych poziomach organizacji systemu, a z drugiej pełnić funkcję certyfikacyjną, w której potwierdzane są umiejętności uczniów i absolwentów w sposób uznawany za wiarygodny dla pracodawców.

\section{Słowa kluczowe:}

zewnętrze egzaminy zawodowe

walidacja

kształcenie zawodowe w Polsce 


\section{Educational and labour market careers of graduates of technical and basic vocational schools}

DOI: 10.47050/65591814.216-243

Michał Sitek

The chapter summarises Polish experiences of implementing external certification of vocational qualications. It presents main motivations and expectations of the new certification system, main changes of the system that were introduced in the last two decades and main challenges faced by the examination system. It emphasises the interdependence of the vocational examinations and other elements of the vocational educational system such as the classification of vocational ocupations and splitting occupations into qualifications. The main challenges identified in the analyses are related to the difficulties in fulfilling the main functions of vocational examinations. On the one hand, examinations are expected to provide information about the quality of education at different levels of the system. On the other, they are expected to fufill the certification function, by certifying that students have sufficient occupational skills in a way that is trustworthy to employers. So far, the system has not been able to fulfill these two functions in the satisfactory way

\section{Keywords:}

external vocational exams

validation

vocational education in Poland 


\section{Wprowadzenie}

Zewnętrzne egzaminy potwierdzające kwalifikacje zawodowe są ważnym elementem systemu kształcenia zawodowego w Polsce, a sam egzamin stał się jednym z podstawowych instrumentów polityki edukacyjnej. W ostatnich kilkunastu latach ich rola i znaczenie istotnie się zmieniały. Przełomowymi wydarzeniami w historii egzaminów zawodowych były: reforma z 1999 r., w ramach której wprowadzono egzaminy zewnętrzne w całym systemie edukacji, oraz reforma kształcenia zawodowego z 2012 r., która podzieliła zawody na kwalifikacje potwierdzane egzaminami i otworzyła dostęp do egzaminów dla innych osób niż absolwenci. Znaczenie egzaminów zawodowych, ewolucja ich funkcji, relacje między egzaminami a potrzebami rynku pracy, a także miejsce egzaminów w Zintegrowanym Systemie Kwalifikacji (ZSK) jest niedocenianą i rzadko opisywaną częścią systemu kształcenia zawodowego w Polsce. W tym rozdziale zostaną podsumowane doświadczenia wdrażania egzaminów zewnętrznych oraz ich słabe i mocne strony.

Wdrożenie systemu oceniania zewnętrznego, w kształceniu zawodowym obowiązującego od 2004 r., oznaczało radykalne zerwanie $z$ istniejącą tradycją i było ogromnym przedsięwzięciem organizacyjnym. Biorąc pod uwagę liczbę zawodów, zróżnicowanie zadań zawodowych i konieczność mierzenia praktycznych umiejętności, przygotowanie i przeprowadzanie egzaminów zawodowych było znacznie trudniejszym przedsięwzięciem niż zorganizowanie egzaminów mierzących wiedzę i umiejętności z matematyki, języka polskiego, przedmiotów przyrodniczych czy języka obcego. Egzamin praktyczny jest też znacznie droższy i wymaga odpowiedniej infrastruktury, co oznacza, że dużym wyzwaniem jest równoważenie względów ekonomicznych i jakości egzaminu. We wprowadzonym w 2004 r. systemie uczniowie zdają dokładnie taki sam egzamin, oceniany według tych samych kryteriów przez przeszkolonych egzaminatorów spoza szkoły, w której odbywa się kształcenie. Zewnętrzny i zestandaryzowany pomiar gwarantuje obiektywność i pozwala porównywać wyniki kształcenia w różnych szkołach i regionach. Taka była też główna motywacja wdrożenia egzaminów zewnętrznych w szkołach ogólnokształcących i zawodowych. W kształceniu zawodowym oczekiwano ponadto, że zewnętrzny egzamin poprawi jakość kształcenia zawodowego i ułatwi absolwentom wchodzenie na rynek pracy. Z kolei zmiany zapoczątkowane w 2012 r. miały także zachęcić dorosłych do dokształcenia się i potwierdzania 
swoich umiejętności przez umożliwienie przystępowania do egzaminów absolwentom nowych, krótkich form kształcenia: osobom, które odbyły kwalifikacyjne kursy zawodowe, oraz dorosłym chcącym potwierdzić swoje umiejętności zdobyte w trakcie pracy i w kształceniu ustawicznym. Czy egzaminy spełniły pokładane w nich nadzieje? Odpowiedź na to pytanie wymaga przyjrzenia się ewolucji systemu egzaminacyjnego i przyjętych w nim rozwiązań.

\section{Funkcje egzaminów w systemie kształcenia zawodowego}

Pojawienie się w polskim systemie kształcenia zawodowego egzaminu zewnętrznego było konsekwencją wdrażania egzaminów zewnętrznych w całym systemie oświaty. W 2002 r. przeprowadzono pierwsze zewnętrzne egzaminy w kształceniu ogólnym (sprawdzian, egzamin gimnazjalny), a pierwsze egzaminy zawodowe zorganizowano dwa lata później. Celem wprowadzenia egzaminów było zrównoważenie decentralizacji systemu oświaty i autonomii programowej szkół. Zgodnie z założeniami reformy z 1999 r. ocenianie zewnętrzne miało przede wszystkim zapewnić lepszą jakość kształcenia, ułatwić porównywalność świadectw szkolnych, a także pozwolić zarówno prześledzić osiągnięcia, jak i zdiagnozować braki edukacyjne uczniów oraz ułatwić ocenę wpływu działań dydaktycznych i wychowawczych nauczycieli w poszczególnych szkołach. Cele te można przyporządkować do różnych funkcji spełnianych przez testy i egzaminy w systemach edukacyjnych (Sitek 2015):

1. funkcja selekcyjna, polegająca na wykorzystaniu wyniku w decyzjach rekrutacyjnych (np. w rekrutacji na uczelnie czy w dostępie do zawodu);

2. funkcja certyfikacyjna, potwierdzanie posiadania odpowiednich kompetencji;

3. funkcja kontrolno-ewaluacyjna, gdzie rolą egzaminów jest dostarczanie obiektywnej, niezależnej od szkół informacji o efektach pracy szkoły;

4. funkcja regulacyjno-motywacyjna, gdzie egzaminy są, w sposób zamierzony lub nie, instrumentem oddziaływania na uczniów, nauczycieli czy dyrektorów szkół (np. poprzez wskazanie, które przedmioty szkolne lub umiejętności są traktowane jako szczególnie ważne). 
$Z$ reguły egzaminy pełnią kilka funkcji równocześnie, ale ich rozróżnienie ma duże znaczenie, ponieważ główny cel egzaminu powinien być odzwierciedlony w sposobie jego organizacji i wpływa on na kryteria oceny stopnia jego realizacji.

W prawie oświatowym podkreśla się znaczenie funkcji kontrolno-ewaluacyjnej egzaminów zewnętrznych: zadaniem Centralnej Komisji Egzaminacyjnej (CKE) jest nie tylko przekazanie wyników uczniom, ale też analizowanie wyników egzaminów i składanie ministrowi właściwemu ds. oświaty i wychowania corocznych sprawozdań w tym zakresie. Z kolei do obowiązków okręgowych komisji egzaminacyjnych należy sporządzanie sprawozdań na podstawie przeprowadzonych analiz i przekazywanie ich dyrektorom szkół, organom prowadzącym szkoły i kuratorom oświaty. W odróżnieniu od egzaminu gimnazjalnego czy matury egzamin zawodowy nigdy nie pełnił funkcji selekcyjnej, a więc nie służył do porównywania wyników osiąganych przez poszczególnych uczniów w celu decyzji rekrutacyjnych na wyższych szczeblach kształcenia. Egzamin zawodowy w kształcie wprowadzonym w 2004 r. miał przede wszystkim odgrywać rolę certyfikacyjną, tj. potwierdzać posiadanie przez absolwentów wiedzy i umiejętności niezbędnych do wykonywania czynności zawodowych 1 . Świadczy o tym m.in. wprowadzenie progu zaliczenia egzaminu i sposób informowania o jego wyniku. Specyfiką systemu kształcenia zawodowego jest też rozłączność procesu nauczania oraz procedury weryfikowania wiedzy i umiejętności zawodowych zdobytych w trakcie nauki. Świadectwo ukończenia szkoły prowadzącej kształcenie zawodowe poświadcza wyłącznie poziom uzyskanego wykształcenia, a nie kwalifikacje zawodowe, które zostają potwierdzone podczas egzaminów. Taka konstrukcja egzaminów powoduje, że korzyści z nich czerpią głównie sami uczący się i pracodawcy. Pracodawców interesuje przede wszystkim to, czy dana osoba dysponuje określonym minimum umiejętności, a nie bardziej zniuansowana informacja o poziomie wiedzy i umiejętności odniesiona do umiejętności innych uczniów. Dokonywanie takich porównań jest trudniejsze także ze względu na to, że za wyjątkiem techników, których absol- 
wenci mogą przystępować do matury, nie weryfikuje się w ocenianiu zewnętrznym umiejętności ogólnych. Certyfikacyjną funkcję egzaminu wzmocniło zlikwidowanie, od 2013 r., powiązania między przystąpieniem do egzaminu i ukończeniem edukacji szkolnej. W przypadku innych egzaminów zewnętrznych przystąpienie do egzaminu zawsze wiąże się z zakończeniem przez ucznia określonego etapu kształcenia. W egzaminach potwierdzających kwalifikacje zawodowe uczniowie mogą przystępować do egzaminu w trakcie nauki, a egzamin mogą zdawać, w określonych przypadkach, także osoby niebędące uczniami.

Konsekwencją funkcji certyfikacyjnej są kryteria oceny tej części systemu egzaminacyjnego. Egzaminy powinny być wiarygodne, uznawane i cenione przez pracodawców i ułatwiać zdobywanie pracy. Z perspektywy pracodawców dostępność informacji o zdaniu przez absolwenta egzaminu jest cenna, zwłaszcza gdy umiejętności zawodowe są trudno weryfikowalne: zatrudnienie osoby wiąże się wówczas z niepewnością i ma konkretny wymiar ekonomiczny. Dostępność wiarygodnego certyfikatu powinna być dla pracodawców wartością, a istnienie zewnętrznego procesu certyfikacji może przyczyniać się do zwiększenia uczestnictwa w zdobywaniu kwalifikacji zawodowych i wzrostu ich wartości na rynku pracy (Acemoglu, Pischke 2000).

Aby uzmysłowić sobie, jaka jest rola egzaminów zewnętrznych w Polsce, warto przyjrzeć się rozwiązaniom stosowanym w innych krajach. Znaczenie i sposób organizacji egzaminów zewnętrznych różnią się w poszczególnych systemach kształcenia zawodowego na świecie. Certyfikacja, rozumiana jako potwierdzanie wiedzy i umiejętności, a nie akredytacja instytucji, jest zazwyczaj domeną państwa, choć w niektórych krajach funkcję tę pełnią inne podmioty, zwykle stowarzyszenia lub inne organizacje niedziałające dla zysku. Kwalifikacje nadawane przez te organizacje są wówczas uznawane przez państwo lub specjalne powołane do tego agencje. Relacje między egzaminami zewnętrznymi a innymi instytucjami odgrywającymi podobną rolę dobrze opisuje podział kwalifikacji w Polsce na kwalifikacje nadawane w systemie oświaty i w szkolnictwie wyższym, kwalifikacje rynkowe, których uzyskiwanie odbywa się na zasadzie swobody działalności gospodarczej, oraz kwalifikacje uregulowane, przyznawane na podstawie przepisów poza systemem oświaty i szkolnictwa wyższego. Proces certyfikacji może być zdecentralizowany. Przykładowo mogą zostać wyznaczone instytucje mające uprawnienia do nadawania certyfikatów, ale w takich 
przypadkach muszą istnieć rozwiązania zapewniające spójność i rzetelność procesu certyfikacji.

Istnienie jednolitych egzaminów zewnętrznych, oprócz jednolitości celów, struktury systemu czy treści kształcenia, jest ważnym wskaźnikiem standaryzacji kształcenia. Jak podkreślają klasyczne już analizy systemów edukacyjnych i powiązań między edukacją a rynkiem pracy, w systemach o wysokim stopniu standaryzacji system edukacji jest zazwyczaj lepiej powiązany ze strukturą zawodową (Allmendinger 1989, s. 239). Przykładem kraju o wysokim poziomie standaryzacji, któremu towarzyszy wyraźny podział na ścieżki kształcenia zawodowego i ogólnego, są Niemcy. Elastyczność możliwości zmiany ścieżki kariery jest w systemie niemieckim ograniczona, ale przejście z edukacji do pracy jest łatwe, a dzięki wspólnie uzgodnionym standardom i szerokim profilom kształcenia zawodowego przechodzenie pracowników z podobnymi kwalifikacjami między firmami jest dużo prostsze. Dużą rolę w tym procesie odgrywa certyfikowanie umiejętności, w którym aktywnie uczestniczą organizacje pracodawców (Busemeyer, Trampusch 2011). W Niemczech w przeprowadzaniu egzaminów biorą udział przedstawiciele izb przemysłowo-handlowych lub rzemieślniczych, a egzaminy w większym stopniu niż w Polsce warunkują możliwość wykonywania zawodu. Egzaminy zewnętrzne weryfikują zakres wymagań uzgodnionych wspólnie przez administrację, pracodawców, szkoleniowców i związki zawodowe. Zewnętrzna certyfikacja i wspólnie uzgodnione standardy kształcenia są ważnym mechanizmem sprzyjającym inwestycjom firm w kształcenie praktyczne (Dustmann, Schönberg 2009). Powiązanie edukacji i rynku pracy jest dużo słabsze w krajach anglosaskich: osiągana pozycja zawodowa jest tam dużo mniej zależna od rodzaju uzyskanego wykształcenia. $Z$ kolei system szkolny jest $w$ dużo większym stopniu nastawiony na kształcenie umiejętności ogólnych. Certyfikacja w krajach anglosaskich i proces kształcenia są rozdzielone, a formalne dyplomy odgrywają dużo mniejszą rolę w procesach rekrutacyjnych. Polskie rozwiązania są unikalne i nawiązują do różnych tradycji. Wynika to ze specyfiki procesu transformacji gospodarczej w Polsce, struktury gospodarki, rozdrobnienia i słabości reprezentacji pracodawców i ich niewielkiego zaangażowania w różne zagadnienia dotyczące kształcenia zawodowego. W polskich rozwiązaniach dotyczących egzaminów zewnętrznych instytucje państwowe odgrywają dużo większą rolę niż w innych krajach. W ostatniej dekadzie kształ- 
cenie zawodowe było pod dużym wpływem rozwiązań anglosaskich, czego odzwierciedleniem jest język efektów uczenia czy promowana w Unii Europejskiej (UE) idea europejskiej i krajowych ram kwalifikacji.

\section{Ewolucja egzaminów zewnętrznych w Polsce}

\section{Egzaminowanie przed 2004 r.}

Przed wprowadzeniem egzaminów zewnętrznych ukończenie szkoły zawodowej traktowano w Polsce jako tożsame z nabyciem kwalifikacji w danym zawodzie. Egzamin przeprowadzano w szkole lub zakładzie pracy, w którym uczniowie (słuchacze) odbywali zajęcia praktyczne. Komisje egzaminacyjne same decydowały o treści egzaminu, który składał się z części praktycznej, przeprowadzanej indywidualnie lub w grupie, oraz części teoretycznej, przeprowadzanej w formie ustnej lub pisemnej. Zwykle część praktyczna przyjmowała formę obrony prac dyplomowych (projektów, modeli, dokumentacji technicznej wykonywanych przez uczniów, często pełniących później rolę pomocy dydaktycznych) lub miała formę egzaminu dyplomowego. Prace dyplomowe - szczególnie w szkołach dla dorosłych - miały charakter praktyczny i często wiązały się z pracą zawodową uczniów. Zdobycie każdego zawodu szkolnego w każdym wypadku wymagało ukończenia pełnego cyklu kształcenia w danym zawodzie, odpowiednio: w zasadniczej szkole zawodowej (dwa lub trzy lata kształcenia), w technikum (cztery lata kształcenia) lub szkole policealnej. Konsekwencją tego rozwiązania było zróżnicowanie poziomów i zakresów wymagań egzaminacyjnych, określanych przez nauczycieli szkół i placówek, w których odbywało się kształcenie.

W dyskusjach dotyczących kierunków zmian w kształceniu zawodowym kwestia certyfikacji miała znaczenie marginalne. Koncepcje zmian koncentrowały się przede wszystkim na modernizacji klasyfikacji zawodów i specjalności szkolnictwa zawodowego i dopasowaniu programów kształcenia do zmieniających się potrzeb gospodarki. Dostrzegano przede wszystkim potrzebę zredukowania listy zawodów. Służyły temu zmiany w klasyfikacjach zawodów i specjalności szkolnictwa zawodowego (1982, 1986), w tym zwłaszcza wprowadzony w 1993 r. tzw. model szerokiego profilu kształcenia. Zmieniały się też wytyczne będące podstawą kształcenia. W latach 90 . były to: dokumentacja programowa dla zawodu (opis zawodu, ramowe plany nauczania i zalecenia dotyczące organizacji procesu dydaktyczno-wychowawczego) 
oraz minima programowe. Wiele nadziei wiązano także z tworzeniem tzw. standardów kwalifikacji, czyli opisu zadań zawodowych, które mogłyby stać się podstawą określania celów i efektów uczenia się w poszczególnych zawodach szkolnych (standardów edukacyjnych), czy modularyzacją programu kształcenia. W przeciwieństwie do kształcenia ogólnego, gdzie już w połowie lat 90 . rozpoczęto prace koncepcyjne nad zewnętrznym egzaminem maturalnym, nie prowadzono badań i analiz dotyczących potwierdzania osiągnięć w kształceniu zawodowym.

\section{Egzaminy zawodowe w starej formule}

We wdrażanej od 1999 r. reformie skupiono się na modelu ustrojowym szkolnictwa: rodzajach szkół, decentralizacji oświaty i związanych z nią kwestiach finansowania edukacji. Nie precyzowano kierunku rozwoju egzaminów zawodowych. Reforma koncentrowała się na kształceniu ogólnym, które miało dominować w systemie oświaty. Wprowadzenie zewnętrznego systemu egzaminowania oraz powołanie CKE i okręgowych komisji egzaminacyjnych umożliwiło objęcie egzaminami także absolwentów szkół zawodowych. Wydaje się, że motywacje były bardzo podobne do tych, które towarzyszyły wprowadzaniu egzaminów w kształceniu ogólnym: dążenie do zwiększenia porównywalności świadectw i stworzenie narzędzi weryfikacji jakości kształcenia. Podjęto też decyzję, i to rozwiązanie funkcjonuje do dziś, że zewnętrzne ocenianie obejmuje jedynie teoretyczne i praktyczne umiejętności zawodowe pozostawiając weryfikację umiejętności ogólnych szkołom i ocenianiu wewnątrzszkolnemu. Postanowiono także, że egzamin zawodowy będzie, podobnie jak egzamin maturalny, dobrowolny.

Zewnętrzny egzamin potwierdzający kwalifikacje zawodowe jest przeprowadzany od $2004 \mathrm{r}$. Na potrzeby wyodrębnienia wiedzy, umiejętności i zadań zawodowych konieczne było wówczas posłużenie się istniejącymi dokumentami: opisem zawodów zawartych w klasyfikacji zawodów i specjalności oraz podstawami programowymi kształcenia w poszczególnych zawodach wpisanymi do klasyfikacji zawodów szkolnictwa zawodowego, które były określane w odrębnych rozporządzeniach. Istniały też inne dokumenty, takie jak przewodnik po zawodach czy teczki informacji zawodowych opracowanych na potrzeby poradnictwa zawodowego. Do kształcenia zawodowego wykorzystywano podobną formułę co w kształceniu ogólnym. Opracowano osobny dokument: standard wymagań egzaminacyjnych, w którym zdefiniowano 
zakres testowanej wiedzy i umiejętności i który na użytek egzaminów uszczegóławiał wymagania dotyczące wiedzy i umiejętności absolwenta pod koniec danego etapu kształcenia. Wprowadzona wówczas formuła funkcjonowała do roku szkolnego 2016/2017 dla tych absolwentów zasadniczych szkół zawodowych, techników, techników uzupełniających i szkół policealnych, którzy rozpoczęli naukę przed 1 września 2012 r.

\section{Nowa formuła egzaminu (od 2013 r.)}

Zmodernizowany egzamin - egzamin potwierdzający kwalifikacje w zawodzie, funkcjonuje od 2013 r. do dziś. Nowe zasady objęły uczniów we wszystkich klasach pierwszych szkół prowadzących kształcenie zawodowe od 1 września 2012 r. Kluczową, także z perspektywy egzaminów, zmianą było wyodrębnienie w poszczególnych zawodach kwalifikacji, ujętych w nowej klasyfikacji zawodów szkolnictwa zawodowego oraz w nowej podstawie programowej kształcenia w zawodach. Zamiast jednego egzaminu na koniec nauki zawodu wprowadzono egzamin potwierdzający kwalifikacje w zawodzie, organizowany dla poszczególnych kwalifikacji, a więc wyodrębnionych w danym zawodzie zestawów oczekiwanych efektów kształcenia (wiedzy i umiejętności).

Nowe założenia $w$ różnym stopniu oddziaływały na poszczególne zawody. W zasadniczej szkole zawodowej uczniowie zdobywają jedną, dwie lub trzy kwalifikacje zawodowe wynikające z programu kształcenia, jednak w tym rodzaju szkół dominowały zawody jednokwalifikacyjne (98). Zawody dwukwalifikacyjne (72) i zawody trójkwalifikacyjne (23) dominują głównie w technikum. Podział zawodów na kwalifikacje stworzył możliwość oddzielnego potwierdzania przez ucznia każdej kwalifikacji odrębnym egzaminem i świadectwem. Poświadczenie wszystkich kwalifikacji wyodrębnionych w zawodzie oraz uzyskanie odpowiedniego poziomu wykształcenia jest warunkiem otrzymania dyplomu potwierdzającego kwalifikacje zawodowe i suplementu do dyplomu. Warto zauważyć, że w zawodach, w których wyodrębniono tylko jedną kwalifikację, egzamin w sposób naturalny jest organizowany, podobnie jak było przed reformą, w ostatnim roku kształcenia. Ideę kwalifikacji wykorzystuje też wdrażana od 2017 r. reforma ustroju szkolnego. Wprowadzenie dwuletniej branżowej szkoły II stopnia ma umożliwiać absolwentom branżowej szkoły I stopnia kontynuację kształcenia zawodowego w systemie szkolnym. W branżowej szkole 
I stopnia realizowane było kształcenie w zakresie jednej kwalifikacji. Drugi stopień branżowej szkoły będzie funkcjonował w zawodach, które mają kontynuację na poziomie technika. Po ukończeniu szkoły II stopnia i po zdaniu egzaminu z zakresu drugiej kwalifikacji absolwent będzie mógł uzyskać wykształcenie średnie branżowe oraz dyplom technika.

Zmiany w egzaminach dotyczyły nie tylko treści i kształtu samego egzaminu, ale też osób, które mogą do niego przystępować. O ile egzamin wprowadzony w 2004 r. był przeznaczony dla absolwentów, to wdrażana od 2012 r. reforma kształcenia zawodowego otworzyła możliwość przystępowania do egzaminu uczniom jeszcze $w$ trakcie nauki ${ }^{2}$. W ten sposób idea kwalifikacji potwierdzanej egzaminem ułatwiała realizację postulatu, pojawiającego się $w$ dyskusjach dotyczących kształcenia zawodowego jeszcze w latach 90., włączenia szkół prowadzących kształcenie zawodowe w system kształcenia ustawicznego. Do egzaminu zostały także dopuszczone osoby mające ukończony kwalifikacyjny kurs zawodowy, praktyczną naukę zawodu dorosłych lub przyuczenie do pracy dorosłych (w rozumieniu ustawy o promocji zatrudnienia), jeżeli program przyuczenia do pracy uwzględniał wymagania określone w podstawie programowej kształcenia w zawodach. Do egzaminu w określonych przypadkach mogą też przystępować osoby dorosłe $w$ trybie eksternistycznym ${ }^{3}$. ustala dyrektor okręgowej komisji egzaminacyjnej w uzgodnieniu z dyrektorem Centralnej Komisji Egzaminacyjnej, a następnie ogłasza go na stronie internetowej okręgowej komisji egzaminacyjnej, nie później niż pięć miesięcy przed ustaloną datą rozpoczęcia egzaminu w zakresie danej kwalifikacji.

System egzaminów eksternistycznych umożliwia uzyskanie wykształcenia odpowiadającego ukończeniu szkoły danego typu. W 2011 r. do istniejących wcześniej rozwiązań dodano możliwość uzyskiwania świadectw potwierdzających kwalifikacje w zawodach oraz dyplomów potwierdzających kwalifikacje zawodowe. Do egzaminu mogą w tym trybie przystąpić osoby dorosłe, mające potwierdzony dwuletni staż pracy, w czasie której wykonywały czynności zgodne z podstawą programową dla danej kwalifikacji. Rozwiązanie to zastąpiło istniejący wcześniej system opierający się na państwowych komisjach egzaminacyjnych powołanych przez kuratorów oświaty do przeprowadzania egzaminów kwalifikacyjnych umożliwiających uzyskanie tytułów zawodowych. 
Tabela 1. Porównanie starego i nowego egzaminu zawodowego

\begin{tabular}{|c|c|c|}
\hline & $\begin{array}{l}\text { egzamin potwierdzający } \\
\text { kwalifikacje zawodowe } \\
\text { (od 2004) }\end{array}$ & $\begin{array}{l}\text { egzamin potwierdzający } \\
\text { kwalifikacje w zawodzie }\end{array}$ \\
\hline okres obowiązywania & 2004-2017 & 2013-2021 \\
\hline zakres egzaminu & $\begin{array}{l}\text { wiedza i umiejętności } \\
\text { w zawodzie }\end{array}$ & $\begin{array}{l}\text { efekty uczenia się } \\
\text { zdefiniowane dla kwalifikacji }\end{array}$ \\
\hline $\begin{array}{l}\text { dokumenty, na podstawie } \\
\text { których opracowywany jest } \\
\text { egzamin }\end{array}$ & $\begin{array}{l}\text { standardy wymagań } \\
\text { egzaminacyjnych }\end{array}$ & $\begin{array}{l}\text { podstawa programowa } \\
\text { kształcenia w zawodzie }\end{array}$ \\
\hline rodzaje zdających & absolwenci & $\begin{array}{l}\text { uczniowie/słuchacze } \\
\text { osoby po kwalifikacyjnych } \\
\text { kursach zawodowych } \\
\text { zdający egzamin w trybie eksternistycznym }\end{array}$ \\
\hline $\begin{array}{l}\text { struktura egzaminu } \\
\text { (próg zdawalności) }\end{array}$ & $\begin{array}{l}\text { etap teoretyczny } \\
\text { (składających się z dwóch } \\
\text { części: wymagane jest } \\
\text { uzyskanie min. } 50 \% \text { i } 30 \% \\
\text { z każdej części) } \\
\text { etap praktyczny }(75 \%)\end{array}$ & $\begin{array}{l}\text { część pisemna (50\%) } \\
\text { część praktyczna (75\%) }\end{array}$ \\
\hline rodzaj certyfikatu & $\begin{array}{l}\text { dyplom potwierdzający } \\
\text { kwalifikacje zawodowe }\end{array}$ & $\begin{array}{l}\text { po zdaniu obu części - świadectwo } \\
\text { potwierdzające kwalifikację w zawodzie } \\
\text { w zakresie jednej kwalifikacji } \\
\text { po zdaniu wszystkich kwalifikacji w zawodzie } \\
\text { i uzupełnieniu wykształcenia ogólnego } \\
\text { na danym poziomie - dyplom potwierdzający } \\
\text { kwalifikacje zawodowe }\end{array}$ \\
\hline
\end{tabular}

Źródło: opracowanie własne.

\section{Podstawy prawne egzaminów i związek}

\section{$z$ innymi rozwiązaniami}

Egzaminy zawodowe są ściśle powiązane z głównymi regulacjami dotyczącymi kształcenia zawodowego: klasyfikacją zawodów szkolnych i podstawami programowymi. Liczba zawodów przekłada się na liczbę rodzajów egzaminów, które trzeba przygotować i przeprowadzić, a w systemie obowiązującym po reformie 2012 r. kluczowe znaczenie ma liczba kwalifikacji. Zadania Centralnej Komisji Egzaminacyjnej i okręgowych komisji egzaminacyjnych, które są odpowiedzialne za prze- 
prowadzenie egzaminu w podlegających im okręgach, określa Ustawa z dnia 7 września 1991 r. o systemie oświaty. Na jej mocy wydawane są przepisy wykonawcze, którymi dla oświaty są głównie rozporządzenia ministra właściwego ds. oświaty i wychowania ogłaszane w Dzienniku Ustaw 4 .

Zasadnicze znaczenie dla systemu egzaminacyjnego ma Rozporządzenie Ministra Edukacji Narodowej z dnia 23 grudnia 2011 r. w sprawie klasyfikacji zawodów szkolnictwa zawodowego, które określa m.in. nazwy zawodów nauczanych w systemie oświaty, obszary kształcenia, do których są przypisane poszczególne zawody, typy szkół ponadgimnazjalnych, w których może odbywać się kształcenie w danym zawodzie, nazwy kwalifikacji wyodrębnionych w zawodzie (lub ich niewyodrębnienie w przypadku zawodów szkolnictwa artystycznego) oraz możliwość prowadzenia kształcenia na kwalifikacyjnych kursach zawodowych w zakresie kwalifikacji wyodrębnionych w zawodzie. Nowa klasyfikacja weszła w życie 1 września 2012 r. i została zastąpiona kolejną 22 grudnia $2016 \mathrm{r}$. W międzyczasie była kilkakrotnie zmieniana: 12 września 2014 r., 1 września i 28 listopada 2015 r. oraz 1 września 2016 r. Zmiany polegały na dodaniu nowych zawodów, zakończeniu kształcenia w niektórych zawodach, wprowadzeniu modyfikacji w zakresie kwalifikacji czy możliwości ich zdobywania w trakcie kwalifikacyjnych kursów zawodowych. Od roku szkolnego 2019/2020 stosuje się "klasyfikację zawodów szkolnictwa zawodowego" określoną w rozporządzeniu w sprawie klasyfikacji zawodów szkolnictwa zawodowego z 13 marca $2017 \mathrm{r}$.

Klasyfikacja zawodów szkolnych wiąże się ściśle z podstawą programową. Reguluje ją rozporządzenie Ministra Edukacji Narodowej z dnia 7 lutego 2012 r. w sprawie podstawy programowej kształcenia w zawodach. W podstawie wyróżnia się kwalifikacje w zawodach, z zakresu

W 2017 r. wiele z zapisów tej ustawy zostało zastąpionych przez nową ustawę: Ustawę z dnia 14 grudnia 2016 r. - Prawo oświatowe oraz akty wykonawcze wydane na jej podstawie. Ponieważ rozwiązania te będą obowiązywać dopiero w przyszłości, w rozdziale odwołujemy się do aktów prawnych, których dotyczy kształcenie uczniów jeszcze nieobjętych reformą ustroju szkolnego. Nowe przepisy, w tym klasyfikacja zawodów, podstawa programowa, będą wdrażane stopniowo, w miarę podejmowania kształcenia przez nowych uczniów lub słuchaczy w poszczególnych typach szkół po wejściu w życie nowego ustroju szkolnego (czyli dla trzyletniej branżowej szkoły I stopnia - od roku szkolnego 2017/2018 w klasie I tej szkoły, pięcioletniego technikum - od roku szkolnego 2019/2020 w klasie I tej szkoły, a dla dwuletniej branżowej szkoły II stopnia - począwszy od roku szkolnego 2020/2021 w klasie I tej szkoły). 
których możliwe jest przeprowadzenie egzaminu. Podstawa wskazuje zestaw oczekiwanych efektów kształcenia: wiedzy i umiejętności zawodowych oraz kompetencji personalnych i społecznych, pozwalających na samodzielne wykonywanie zadań zawodowych w poszczególnych kwalifikacjach. Efekty kształcenia podzielono na efekty wspólne dla wszystkich zawodów (np. dotyczące bezpieczeństwa i higieny pracy), wspólne dla wszystkich zawodów w ramach obszaru kształcenia oraz właściwe dla kwalifikacji wyodrębnionych w zawodach. Podstawa programowa jest bazą do tworzenia zarówno kryteriów ocen szkolnych, jak i wymagań egzaminacyjnych nowego egzaminu zawodowego. Dzięki temu nastąpiło ujednolicenie wymagań w zakresie kształcenia i egzaminowania.

Przebieg egzaminu oraz zasady jego przeprowadzania i oceniania opisuje rozporządzenie Ministra Edukacji Narodowej z dnia 30 kwietnia 2007 r. w sprawie warunków i sposobu oceniania, klasyfikowania i promowania uczniów i słuchaczy oraz przeprowadzania sprawdzianów i egzaminów w szkołach publicznych oraz rozporządzenie Ministra Edukacji Narodowej z 27 kwietnia 2015 r. w sprawie szczegółowych warunków i sposobu przeprowadzania egzaminu potwierdzającego kwalifikacje w zawodzie.

Wśród aktów prawnych wpływających na kształt egzaminu znaczenie ma także rozporządzenie Ministra Edukacji Narodowej z dnia 11 stycznia 2012 r. w sprawie egzaminów eksternistycznych. Określa ono m.in. warunki dopuszczania do egzaminu eksternistycznego potwierdzającego kwalifikacje w zawodzie w ramach danej kwalifikacji, wysokość opłat pobieranych za egzamin eksternistyczny w zakresie jednej kwalifikacji oraz wykaz zawodów, w których nie przeprowadza się egzaminów zawodowych w trybie eksternistycznym.

Egzamin obejmuje jedną kwalifikację, więc liczba egzaminów w danym zawodzie wymaganych do uzyskania dyplomu potwierdzającego wszystkie kwalifikacje zależy od liczby wyodrębnionych w nim kwalifikacji. W założeniach systemu część kwalifikacji była wspólna dla kilku zawodów. W zawodach nauczanych w technikum pierwszą kwalifikacją (K 1) jest często ta sama kwalifikacja, która została ustalona dla zawodu nauczanego w zasadniczej szkole zawodowej. Stanowi ona merytoryczną i programową podbudowę nabywania kolejnych - często wyższych, bo na poziomie technika - kwalifikacji w zawodzie w ramach tego samego obszaru kształcenia. Jeśli kwalifikacja, z zakresu której 
uczeń zdał egzamin w określonym zawodzie, jest wyodrębniona również w innym zawodzie (jest kwalifikacją wspólną dla różnych zawodów), to uczeń może uzyskać kwalifikację również w tym innym zawodzie przez zdanie egzaminu z zakresu kolejnej (kolejnych) kwalifikacji właściwej dla tego zawodu.

Dokumentem potwierdzającym osiągnięcie przez ucznia efektów kształcenia w zawodzie w zakresie jednej kwalifikacji jest świadectwo wydawane przez okręgową komisję egzaminacyjną. Osoba, która posiada świadectwa potwierdzające wszystkie kwalifikacje wyodrębnione w danym zawodzie oraz odpowiedni poziom wykształcenia ogólnego dla danego zawodu, otrzymuje dyplom poświadczający kwalifikacje zawodowe. Na wniosek absolwenta do dyplomu zaświadczającego o posiadaniu kwalifikacji zawodowych dołącza się jeden z dokumentów Europass - Suplement do Dyplomu Potwierdzającego Kwalifikacje Zawodowe, w języku angielskim i w formacie wspólnym dla całej Unii Europejskiej. Stanowi on uzupełnienie informacji zawartych w dyplomie i ma za zadanie ułatwić lepsze zrozumienie dokumentacji kwalifikacji, przede wszystkim pracodawcom i instytucjom zagranicznym. Dyplomy i suplementy do dyplomów są wydawane przez okręgowe komisje egzaminacyjne.

\section{Egzaminy w rzemiośle}

Równolegle do rozwiązań w edukacji formalnej funkcjonują mające dużo dłuższą tradycję egzaminy w rzemiośle. Działalność rzemiosła jest regulowana odrębną ustawą. Rzemiosło ma swój samorząd gospodarczy, w którego skład wchodzą: Związek Rzemiosła Polskiego, będący ogólnopolską, społeczno-zawodową organizacją pracodawców, oraz organizacje terenowe - izby rzemieślnicze, cechy rzemiosł i spółdzielnie, które łącznie zrzeszają ok. 300 tys. firm i przedsiębiorców. Rzemiosło prowadzi szkoły zgodnie z podstawami programowymi kształcenia zawodowego lub kształci $w$ formie programu przygotowania zawodowego młodocianych pracowników. W drugim przypadku nauka zawodu przebiega w dwóch równolegle realizowanych etapach: praktycznym, zorganizowanym w zakładzie rzemieślniczym, i teoretycznym, zorganizowanym w szkole zawodowej bądź na kursach dokształcających.

Podstawą prawną systemu egzaminów czeladniczych i mistrzowskich przeprowadzanych przez komisje egzaminacyjne powołane przez izby rzemieślnicze jest Ustawa z dnia 22 marca 1989 r. o rzemiośle (oraz 
wydane na podstawie zawartej w niej delegacji rozporządzenie Ministra Edukacji Narodowej z dnia 14 września 2012 r. w sprawie egzaminu czeladniczego, egzaminu mistrzowskiego oraz egzaminu sprawdzającego, przeprowadzanych przez komisje egzaminacyjne izb rzemieślniczych). Dokument ten określa szczegółowe warunki i tryb powołania komisji oraz przeprowadzania egzaminów, a także warunki dopuszczenia do nich. Izby rzemieślnicze mają prawo egzaminować w prawie 120 zawodach, w tym 49 zawodach szkolnych. Wśród zawodów rzemieślniczych jest wiele zawodów rękodzielniczych i niszowych, takich jak zdun, witrażownik, rzeźbiarz w drewnie, juhas czy baca.

Podobnie jak w formalnym systemie kształcenia egzamin czeladniczy i egzamin mistrzowski są oceną poziomu opanowania wiadomości i umiejętności z zakresu zawodu odpowiadającego danemu rodzajowi rzemiosła. Tym, co wyróżnia kształcenie w rzemiośle, jest otwartość systemu i dostępność dla różnych grup kandydatów, tj. zarówno młodocianych absolwentów nauki zawodu u rzemieślnika, a także osób dorosłych, poszukujących możliwości potwierdzenia kwalifikacji nabytych w pracy zawodowej i przygotowania teoretycznego. Kandydat na czeladnika ma siedem możliwości dojścia do egzaminu. Oprócz ukończenia nauki zawodu uwzględnia się także poziom wykształcenia, potwierdzone kwalifikacje zawodowe, okres wykonywania zawodu oraz świadectwo ukończenia gimnazjum albo ośmioletniej szkoły podstawowej lub ponadgimnazjalnej. Kandydat na mistrza ma sześć możliwości dojścia do egzaminu mistrzowskiego, uwzględniających również wykształcenie, kwalifikacje zawodowe ( $w$ tym posiadanie tytułu czeladnika), okres wykonywania zawodu, w którym zdaje egzamin doświadczenie zawodowe oraz świadectwo ukończenia co najmniej szkoły ponadgimnazjalnej.

W odróżnieniu od egzaminów OKE praktyczna część egzaminów czeladniczych i mistrzowskich trwa od 120 minut do 24 godzin. Są one przeprowadzane przez komisje egzaminacyjne izb rzemieślniczych. Zadania egzaminacyjne i zestawy pytań na oba etapy przygotowuje zespół egzaminacyjny, a zatwierdza je izba rzemieślnicza. Nadzór nad działalnością komisji egzaminacyjnych izb rzemieślniczych sprawuje ZRP. W rzemiośle członkami komisji muszą być osoby z wysokimi kwalifikacjami zawodowymi. Przewodniczący musi posiadać wykształcenie wyższe oraz sześcioletni staż w zawodzie, a członkowie - minimum zasadnicze, tytuł mistrza i trzyletni staż w zawodzie. Od tej zasady są 
jednak wyjątki: w zawodach unikatowych wystarczy posiadanie średniego wykształcenia, tytułu mistrza i trzyletniego stażu w zawodzie. Granice między systemem egzaminów organizowanych przez izby rzemieślnicze i okręgowe komisje egzaminacyjne są nieostre. Uczniowie młodociani - choć z zasady przystępują do egzaminu przed izbą rzemieślniczą - mogą również przystąpić do egzaminu organizowanego przez OKE (jako uczniowie ZSZ).

Rozwiązania wdrażane od 1 września 2012 r. stwarzają nowe możliwości nie tylko dla uczniów i absolwentów szkół zawodowych, ale także dla osób, które wiedzę, umiejętności i kompetencje społeczne niezbędne do właściwej realizacji zadań zawodowych uzyskały w formach pozaszkolnych oraz w wyniku samodzielnego uczenia się. Duże znaczenie mają kwalifikacyjne kursy zawodowe przeznaczone przede wszystkim dla osób dorosłych. Są one prowadzone z uwzględnieniem podstawy programowej kształcenia w zawodach w zakresie efektów kształcenia wyodrębnionych w ramach danej kwalifikacji albo wspólnych dla wszystkich zawodów i dla zawodów w ramach obszaru kształcenia, stanowiących podbudowę nauczania w zawodzie lub grupie zawodów, bądź w zakresie efektów kształcenia wspólnych dla wszystkich zawodów w zakresie organizacji pracy małych zespołów. Kurs kończy się zaliczeniem w formie ustalonej przez organizatora, a osoba, która je uzyskała, otrzymuje świadectwo ukończenia kursu umiejętności zawodowych. Osoby, które chcą uzyskać dyplom w zawodzie poprzez kwalifikacyjne kursy zawodowego, a które nie mają wykształcenia ogólnego na poziomie zasadniczej szkoły zawodowej, mogą ukończyć kursy kompetencji ogólnych - prowadzone na podstawie programu nauczania uwzględniającego dowolnie wybraną część podstawy programowej kształcenia ogólnego. Kurs kończy się zaliczeniem w formie ustalonej przez organizatora, a osoba, która je uzyskała, otrzymuje świadectwo ukończenia kursu kompetencji ogólnych. Pierwsze kwalifikacyjne kursy zawodowe uruchomiono we wrześniu 2012 r.

\section{Przebieg egzaminu}

Egzamin zawodowy składa się z dwóch części (dawniej etapów): pisemnej i praktycznej. Pisemna część egzaminu ma formę testu, który odbywał się z wykorzystaniem wydrukowanych arkuszy egzaminacyjnych i kart odpowiedzi albo komputera. Od 2017 r. ma postać wyłącznie elektroniczną. W starej formule na etapie pisemnym w pierwszej części 
sprawdzano wiadomości i umiejętności z zakresu kwalifikacji w konkretnym zawodzie, w drugiej - wiadomości i umiejętności związane z zatrudnieniem i działalnością gospodarczą wspólne dla wszystkich zawodów. W nowym egzaminie zrezygnowano z części wspólnej. Część pisemną skrócono ze 120 do 60 minut.

Etap praktyczny w zależności od zawodu trwa 120-240 minut i polega na wykonaniu zadań sprawdzających praktyczne umiejętności z zakresu kwalifikacji w danym zawodzie 5 . Część praktyczna egzaminu zawodowego odbywa się na stanowisku egzaminacyjnym i w założeniu ma jak najlepiej oddawać naturalne warunki przyszłej pracy. Zdający wykonuje zadanie z arkusza egzaminacyjnego, które najczęściej jest próbą pracy. $\mathrm{Na}$ zapoznanie się z treścią zadania i wyposażeniem stanowiska ma dodatkowe 10 minut. Egzaminy praktyczne mogą być przeprowadzane wyłącznie w ośrodkach mających niezbędną infrastrukturę. Po zakończeniu części praktycznej egzaminu zawodowego zdający opuszczają salę egzaminacyjną, pozostawiając na swoich stanowiskach efekty wykonania zadania egzaminacyjnego oraz związaną z nim dokumentację.

W większości kwalifikacji rezultatem zadania praktycznego jest wyrób lub usługa, które są oceniane w trakcie egzaminu. W niektórych kwalifikacjach rezultatem zadania jest dokumentacja, oceniana przez egzaminatorów po przesłaniu prac do komisji egzaminacyjnych. Egzaminator analizuje nie tylko produkt, lecz także cały proces jego tworzenia. Każdy z trzech egzaminatorów ocenia:

1. jakość rezultatu końcowego: wyrobu, usługi lub dokumentacji, pod względem spełnienia wymagań określonych w zadaniu egzaminacyjnym zawartym w arkuszu egzaminacyjnym;

2. jakość rezultatu pośredniego, w przypadku gdy jego ocena ma bezpośredni wpływ na ocenę jakości rezultatu końcowego, a nie jest możliwa po wykonaniu zadania egzaminacyjnego zawartego w arkuszu egzaminacyjnym;

3. przebieg wykonania zadania egzaminacyjnego zawartego $w$ arkuszu egzaminacyjnym pod względem przestrzegania przepisów bezpieczeństwa i higieny pracy, zgodności z metodami lub technologiami właściwymi do wykonania zadania egzaminacyjnego zawartego $w$ arkuszu egzaminacyjnym.

$5 \quad$ Opisany przykład egzaminu i sposobu jego oceniania w wybranych kwalifikacjach można znaleźć w: Szmigel, Szaleniec 2017. 
Wynik egzaminu zawodowego ustala okręgowa komisja egzaminacyjna. Zdający zalicza egzamin zawodowy, jeżeli uzyska z części pisemnej co najmniej $50 \%$ punktów możliwych do uzyskania (czyli rozwiązał poprawnie minimum 20 z 40 zadań testu pisemnego), a z części praktycznej co najmniej 75\% punktów możliwych do uzyskania (czyli 75 ze 100 możliwych punktów do uzyskania). Część praktyczną egzaminu zawodowego obserwują i oceniają obecni w sali egzaminacyjnej egzaminatorzy wpisani do ewidencji egzaminatorów w zakresie przeprowadzania egzaminu potwierdzającego kwalifikacje w zawodzie. Egzaminatorem nie może być nauczyciel zatrudniony w szkole lub placówce, w której odbywa się część praktyczna egzaminu zawodowego. Wszystkie te osoby muszą mieć przygotowanie pedagogiczne oraz ukończone 18-godzinne szkolenie dla kandydatów na członka komisji.

\section{Zmiany liczby kwalifikacji i statystyki egzaminów}

Egzaminy wprowadzano stopniowo: w czerwcu 2004 r. został przeprowadzony dla absolwentów dwuletnich zasadniczych szkół zawodowych w 15 zawodach. W kolejnych latach rosła liczba zdających: w sesji letniej $2006 \mathrm{r}$. do egzaminu w 129 zawodach przystąpiło 142 tys., a w 2007 r. 169,5 tys. osób w 156 zawodach. Pod względem liczby zdających rekordowe były lata 2012 i 2013, gdy egzamin zorganizowano odpowiednio w 170 i 175 zawodach, a zdawało go odpowiednio 240 tys. i 231 tys. absolwentów.

Już od pierwszych egzaminów problemem była niska zdawalność. W pierwszej edycji egzaminu etap teoretyczny zdało $76 \%$ przystępujących, praktyczny 82\%, a cały egzamin 63\% zdających. W 2006 r., gdy egzaminy obejmowały już znacznie więcej zawodów i zdających, dyplomy otrzymało $62 \%$ osób, a rok później $56,4 \%$ (na co wpłynęła przede wszystkim niska zdawalność, ok. $51 \%$, części praktycznej). W późniejszych latach odsetek osób, które zdały obie części egzaminu, był stabilny i wynosił ok. 66-68\% przystępujących.

Egzaminy zawodowe w nowej formule (dla kwalifikacji) przeprowadzono w 2013 r. Nowy egzamin objął tych, którzy rozpoczęli naukę po 1 września 2012 r. lub którzy przystępowali do egzaminu w trybie eksternistycznym. Oznacza to, że okręgowe komisje egzaminacyjne w latach 2013-2017 przeprowadzały zarówno stary, jak i nowy egzamin zawodowy. W kolejnych latach coraz mniej osób przystępowało do 
starego, a coraz więcej do nowego egzaminu zawodowego6. W 2013 r. na zdawanie egzaminu potwierdzającego kwalifikacje zdecydowało się 24,6 tys. uczniów, a kwalifikacje udało się potwierdzić 14,4 tys., czyli zaledwie $60 \%$. Jesienią 2014 r. przeprowadzono egzaminy dla 138 kwalifikacji, co stanowiło $55 \%$ ich ogółu. W kolejnych latach stopniowo zwiększała się liczba przystępujących. W latach 2015-2017 w sesji letniej brało udział każdorazowo prawie ćwierć miliona osób. Spora część uczniów uczestniczyła też w sesji zimowej.

Tabela 2. Liczba przystępujących i zdawalność egzaminów (w stosunku do liczby przystępujących) w nowej formule egzaminu w latach 2013-2017*

\begin{tabular}{|c|c|c|c|c|c|c|c|c|}
\hline & & $\begin{array}{c}\text { liczba } \\
\text { kwalifi- } \\
\text { kacji }\end{array}$ & $\begin{array}{c}\text { przystąpiło } \\
\text { do obu } \\
\text { części } \\
\text { (w tys.) }\end{array}$ & $\begin{array}{c}\text { przystąpiło } \\
\text { do części } \\
\text { pisemnej } \\
\text { (w tys.) }\end{array}$ & $\begin{array}{c}\text { przystąpiło } \\
\text { do części } \\
\text { praktycznej } \\
\text { (w tys.) }\end{array}$ & $\begin{array}{c}\text { zdawalność } \\
\text { obu części } \\
\text { (w \%) }\end{array}$ & $\begin{array}{c}\text { zdawalność } \\
\text { części } \\
\text { pisemnej } \\
(w \%)\end{array}$ & $\begin{array}{c}\text { zdawalność } \\
\text { części } \\
\text { praktycznej } \\
\text { (w \%) }\end{array}$ \\
\hline \multirow[t]{2}{*}{2013} & $\begin{array}{l}\text { VIII- } \\
\text { IX }\end{array}$ & 2 & 0,4 & 0,5 & 0,4 & 94 & 95 & 98 \\
\hline & $X-X I$ & 69 & 2,1 & 2,3 & 2,3 & 60 & 80 & 69 \\
\hline \multirow{3}{*}{2014} & $|-I|$ & 78 & 24,1 & 25,4 & 27,0 & 54 & 86 & 58 \\
\hline & V-VII & 138 & 118,5 & 120,9 & 121,6 & 65 & 82 & 73 \\
\hline & VIII-X & 127 & 11,9 & 13,1 & 14,6 & 68 & 83 & 71 \\
\hline \multirow{3}{*}{2015} & I-II & 146 & 66,7 & 76,4 & 80,5 & 69 & 82 & 75 \\
\hline & V-VII & 195 & 237,2 & 244,5 & 245,5 & 72 & 83 & 84 \\
\hline & VIII-X & 192 & 15,0 & 19,8 & 20,4 & 70 & 77 & 76 \\
\hline \multirow{4}{*}{2016} & I-II & 212 & 164,0 & 187,3 & 184,2 & 71 & 85 & 75 \\
\hline & IV, VI & 2 & 1,3 & 1,3 & 1,3 & 99 & 100 & 98 \\
\hline & V-VI & 211 & 239,1 & 249,0 & 246,7 & 76 & 86 & 84 \\
\hline & VIII-X & 192 & 13,2 & 21,3 & 28,7 & 68 & 71 & 58 \\
\hline \multirow{3}{*}{2017} & I-II & 220 & 157,5 & 176,2 & 179,1 & 73 & 87 & 74 \\
\hline & V-VI & 2 & 1,6 & 1,6 & 1,6 & 97 & 99 & 97 \\
\hline & VI-VII & 223 & 241,3 & 253,9 & 250,5 & 78 & 88 & 84 \\
\hline
\end{tabular}

* Podczas interpretacji danych należy pamiętać, że uczniowie, którzy nie zdali konkretnej części egzaminu, mogą przystąpić do egzaminu po raz kolejny, a sesje egzaminacyjne są organizowane nie dla wszystkich kwalifikacji.

Źródło: opracowanie własne na podstawie sprawozdań CKE.

6 Przykładowo w sesji letniej w 2016 r. do egzaminu zawodowego w starej formule podeszło 13,8 tys. absolwentów w 137 zawodach, a w 2017 r. było to 3,8 tys. absolwentów w 81 zawodach. 
CKE co roku publikuje sprawozdanie z wyników przeprowadzonych egzaminów. Interpretacja raportowanych danych w skali całego systemu nie jest jednak prosta. Egzaminy są organizowane kilka razy w roku, przy czym część sesji odbywa się tylko dla wybranych kwalifikacji, zdający mogą powtórnie przystępować do egzaminów lub ich części, a zadania nie są porównywalne $w$ czasie. $Z$ tego powodu trudno ocenić, czy zmiana poziomu zdawalności egzaminów jest efektem wyższych umiejętności zdających czy też wynika z różnej trudności samego egzaminu. W przypadku kwalifikacji ujętych w programach zasadniczych szkół zawodowych i techników statystyki przedstawiane w sprawozdaniu CKE nie uwzględniają też rozróżnienia na rodzaje szkół. $Z$ tego względu raporty mają w dużej mierze charakter sprawozdawczy i niewiele mówią o jakości kształcenia. $Z$ tego punktu widzenia bardziej cenne są zdezagregowane wyniki przedstawiane w sprawozdaniach okręgowych komisji egzaminacyjnych. Część OKE przedstawia wyniki na poziomie powiatów i pojedynczych szkół, a niektóre pokazują też wyniki dla osób przystępujących do egzaminu po raz pierwszy. Najbardziej szczegółowe informacje są dostępne dla dyrektorów szkół, którzy mogą uzyskać informacje o wynikach własnych uczniów i absolwentów i zestawiać je z innymi informacjami o swoich uczniach i absolwentach.

Aby przystąpić do egzaminu potwierdzającego kwalifikacje w zawodzie, należy złożyć pisemną deklarację lub wniosek, który pozwala zaplanować prace komisjom egzaminacyjnym. Osoby, które nie zdały obydwu lub jednej części egzaminu, nie przystąpiły do egzaminu w wyznaczonym terminie lub go przerwały, mogą ponownie przystąpić do egzaminu z niezdanej części. Oznacza to, że uczeń może podchodzić do egzaminu kilkakrotnie w trakcie nauki. Po ukończeniu szkoły może ponownie przystąpić do egzaminu jeszcze tylko dwukrotnie, na zasadach określonych dla absolwentów. Przystąpienie do egzaminu po raz trzeci lub kolejny po zakończeniu nauki odbywa się na warunkach określonych dla egzaminu eksternistycznego. Po upływie trzech lat od dnia, w którym zdający przystąpił do części pisemnej egzaminu i nie zdał lub mógł przystąpić po raz pierwszy do części pisemnej egzaminu (na podstawie złożonej deklaracji), przystępuje do egzaminu w pełnym zakresie.

Aby zilustrować złożoność danych z egzaminów potwierdzających kwalifikacje, warto przyjrzeć się konkretnej sesji egzaminacyjnej. W czerwcu i w lipcu 2017 r. egzamin przeprowadzono w całej Polsce dla 223 kwalifikacji. Do obu części egzaminu przystąpiło 241,3 tys. 
osób. Liczba osób przystępujących do potwierdzenia poszczególnych kwalifikacji była bardzo zróżnicowana. W przypadku 14 kwalifikacji do egzaminu przystępowało mniej niż pięć osób, a trzy najpopularniejsze zdawało po 15-17 tys. osób (Sporządzanie potraw i napojów; Projektowanie lokalnych sieci komputerowych i administrowanie sieciami; Montaż i eksploatacja komputerów osobistych oraz urządzeń peryferyjnych). Mediana zdających (dla wszystkich 223 kwalifikacji) wyniosła 165 osób. Egzamin w obu częściach zdało $78 \%$ osób.

Tabela 3. Liczba kwalifikacji i zdawalność egzaminów (w przeliczeniu na kwalifikacje) w obszarach klasyfikacji zawodów szkolnych w sesji letniej 2017 r.

\begin{tabular}{|c|c|c|c|c|c|}
\hline obszar & $\begin{array}{c}\text { liczba } \\
\text { kwalifikacji }\end{array}$ & $\begin{array}{l}\text { średnia liczba } \\
\text { zdających } \\
\text { obie części }\end{array}$ & $\begin{array}{l}\text { zdawalność } \\
\text { części } \\
\text { teoretycznej } \\
\text { (w \%) }\end{array}$ & $\begin{array}{c}\text { zdawalność } \\
\text { części } \\
\text { praktycznej } \\
(\text { w \% })\end{array}$ & $\begin{array}{c}\text { zdawalność } \\
\text { obu części } \\
\text { (w \%) }\end{array}$ \\
\hline A-administracyjno-usługowy & 54 & 1314,5 & 80 & 76 & 63 \\
\hline B - budowlany & 32 & 606,1 & 87 & 86 & 78 \\
\hline E-elektryczno-elektroniczny & 26 & 2041,2 & 64 & 75 & 52 \\
\hline $\begin{array}{l}\text { M-mechaniczny i górniczo- } \\
\text {-hutniczy }\end{array}$ & 42 & 644,5 & 70 & 78 & 62 \\
\hline $\begin{array}{l}\mathrm{R} \text { - rolniczo-leśny z ochroną } \\
\text { środowiska }\end{array}$ & 24 & 750,8 & 86 & 75 & 65 \\
\hline S - artystyczny & 8 & 42,6 & 84 & 91 & 77 \\
\hline $\begin{array}{l}\text { T- turystyczno-gastrono- } \\
\text {-miczny }\end{array}$ & 16 & 1985,9 & 91 & 84 & 80 \\
\hline Z-medyczno-społeczny & 21 & 983,2 & 94 & 87 & 84 \\
\hline ogółem/średnia* & 223 & $1082,1^{*}$ & $80^{*}$ & $80^{*}$ & $68^{*}$ \\
\hline
\end{tabular}

* średnia dla wszystkich kwalifikacji

Źródło: opracowanie własne na podstawie danych przedstawionych w sprawozdaniu CKE.

Zdawalność poszczególnych kwalifikacji była bardzo różna, a średnią zaniżają kwalifikacje, w których było bardzo mało zdających. W niemal każdym obszarze kształcenia można znaleźć kwalifikacje, gdzie zdawalność przekraczała $90 \%$. Zdawalność była najbardziej zróżnicowana w kwalifikacjach z obszaru mechanicznego i górniczo-hutniczego, a najmniej w obszarze turystyczno-gastronomicznym. 
Tabela 4. Zróżnicowanie zdawalności egzaminów (z obu części) w ramach poszczególnych kwalifikacji w podziale na obszar kształcenia w sesji letniej 2017 r.

\begin{tabular}{|c|c|c|c|c|c|c|c|}
\hline obszar & $\begin{array}{c}10 \% \\
\text { lub mniej }\end{array}$ & $\begin{array}{c}\text { między } \\
10 \text { a } 25 \%\end{array}$ & $25-50 \%$ & $50-75 \%$ & $75-90 \%$ & $\begin{array}{c}\text { powyżej } \\
90 \%\end{array}$ & łącznie \\
\hline A-administracyjno-usługowy & 3 & 5 & 5 & 20 & 14 & 7 & 54 \\
\hline B - budowlany & 0 & 1 & 2 & 8 & 12 & 9 & 32 \\
\hline E- elektryczno-elektroniczny & 2 & 2 & 8 & 8 & 5 & 1 & 26 \\
\hline $\begin{array}{l}\text { M- mechaniczny i górniczo- } \\
\text {-hutniczy }\end{array}$ & 8 & 0 & 3 & 11 & 12 & 8 & 42 \\
\hline $\begin{array}{l}\mathrm{R} \text { - rolniczo-leśny z ochroną } \\
\text { środowiska }\end{array}$ & 1 & 0 & 6 & 8 & 4 & 5 & 24 \\
\hline S-artystyczny & 1 & 0 & 0 & 1 & 3 & 3 & 8 \\
\hline $\mathrm{T}$ - turystyczno-gastronomiczny & 0 & 0 & 0 & 6 & 5 & 5 & 16 \\
\hline Z-medyczno-społeczny & 1 & 0 & 1 & 1 & 7 & 11 & 21 \\
\hline ogółem & 16 & 8 & 25 & 63 & 62 & 49 & 223 \\
\hline
\end{tabular}

Źródło: opracowanie własne na podstawie danych przedstawionych w sprawozdaniu CKE.

Największą grupę zdających stanowili uczniowie (88\%), mniejszość kursanci (niecałe 6\%), absolwenci (ok. 5\%) i nieliczna grupa eksternów. Zdawalność była wyraźnie wyższa wśród eksternów i kursantów i niższa wśród uczniów i absolwentów.

Tabela 5. Liczba przystępujących do egzaminu potwierdzającego kwalifikacje w zawodzie oraz zdawalność egzaminów w podziale na rodzaje zdających w sesji letniej 2017 r.

\begin{tabular}{l|c|c|c|c|c|c|c} 
& $\begin{array}{c}\text { liczba } \\
\text { przystępują- } \\
\text { cych do obu } \\
\text { części } \\
\text { (w tys.) }\end{array}$ & $\begin{array}{c}\text { liczba } \\
\text { kwalifikacji } \\
\text { w części } \\
\text { pisemnej } \\
\text { (w tys.) }\end{array}$ & $\begin{array}{c}\text { liczba } \\
\text { kwalifikacji } \\
\text { w części } \\
\text { praktycznej } \\
\text { (w tys.) }\end{array}$ & $\begin{array}{c}\text { liczba } \\
\text { kwalifikacji } \\
\text { zdawanych } \\
\text { obu części } \\
\text { (w tys.) }\end{array}$ & $\begin{array}{c}\text { średnia } \\
\text { zdawalność } \\
\text { części } \\
\text { pisemnej } \\
(\text { w \%) }\end{array}$ & $\begin{array}{c}\text { średnia } \\
\text { zdawalność } \\
\text { części } \\
\text { praktycznej } \\
(\text { w \%) }\end{array}$ & $\begin{array}{c}\text { średnia } \\
\text { zdawalność } \\
\text { obu części }\end{array}$ \\
\hline uczeń & 215,6 & 203 & 203 & 199 & 82 & 80 & 70 \\
\hline absolwent & 13,2 & 166 & 170 & 133 & 70 & 74 & 59 \\
\hline kursant & 14,1 & 121 & 120 & 116 & 91 & 83 & 79 \\
\hline ekstern & 0,4 & 65 & 77 & 63 & 94 & 84 & 84
\end{tabular}


Zdawalność jest powszechnie traktowana jako ważny wskaźnik jakości kształcenia. Uwzględniają ją w swoich sprawozdaniach jednostki samorządu terytorialnego, jest to też od lat miernik sprawności państwa uwzględniony w opracowywanym przez Ministerstwo Finansów Wieloletnim Planie Finansowym Państwa. W najnowszej edycji dąży się do osiągnięcia w 2021 r. wartości 72\% (Wieloletni Plan Finansowy... 2018, s. 67). Tymczasem wskaźniki zdawalności trudno interpretować jako miary efektywności kształcenia. Jeden z najlepszych wyników uzyskały osoby zdające egzamin na kwalifikację B.01. „Eksploatacja maszyn i urządzeń drogowych", w której wszyscy ze 381 zdających byli absolwentami kwalifikacyjnych kursów zawodowych. Na tak dobry wynik mogło wpłynąć to, że tylko część uczestników kursu go ukończyła i tylko część zdecydowała się przystąpić do egzaminu, a także to, że egzamin ten był relatywnie łatwiejszy dla zdających. Porównanie wyłącznie liczby przystępujących i zdających egzamin nie daje więc informacji o skuteczności kursu. Problematyczna jest także arbitralność przyjętych progów zdawalności, które są takie same we wszystkich kwalifikacjach. W przypadku innych egzaminów, do których mogą przystępować zarówno uczniowie, jak i osoby, które mają już za sobą doświadczenie pracy, interpretacja wyników jest jeszcze trudniejsza.

\section{Wyzwania}

Egzaminy zawodowe pełnią w polskim systemie różne funkcje, z którymi wiążą się różne kryteria efektywności. Jak podkreśla uzasadnienie rządowego projektu zmian zasad kształcenia zawodowego z 2018 r., egzaminy potwierdzające kwalifikacje "powinny z jednej strony weryfikować jakość procesu kształcenia, a z drugiej stanowić przepustkę do sukcesu na rynku pracy" (druk sejmowy nr 2861, uzasadnienie, s. 4). Osiąganie obu tych celów było jak dotąd problematyczne.

Pogłębioną diagnozę systemu egzaminacyjnego przed reformą $2012 \mathrm{r}$. przeprowadzono w latach 2008-2009 (Drogosz-Zabłocka, Kochanowski 2009). Wskazywano wówczas na niską jakość testów egzaminacyjnych, które skłaniały do podporządkowywania odpowiedzi kluczowi oceniania, ich schematyczność i brak branżowego podejścia wynikającego ze zbytniego ujednolicania wymagań. Podkreślano też ogólniejszy problem relacji między testami, podstawą programową i realiami wymagań zawodowych. Prowadziło to do sytuacji, że egzaminy nie cieszyły się wysokim prestiżem u pracodawców i były słabym wskaźnikiem 
posiadania umiejętności zawodowych wymaganych w realiach rynku pracy (Sztanderska, Wojciechowski 2008, s. 38). W ciągu dziesięciu lat sytuacja znacznie się poprawiła, także dzięki inwestycjom z funduszy strukturalnych w poprawę jakości zadań egzaminacyjnych czy e-ocenianie. Przede wszystkim poprawiono powiązanie testów z podstawą programową i zdefiniowanymi w niej efektami uczenia. Udoskonalano także procedury egzaminacyjne i kompetencje egzaminatorów. Ale jakość i dostępność infrastruktury technicznej wciąż nie jest odpowiednia w nauce niektórych zawodów, a dyrektorzy skarżą się na niewystarczającą liczbę odpowiednio wyposażonych pracowni i stanowisk egzaminacyjnych (np. Pfeiffer 2015). Konieczność przeprowadzania takiego samego egzaminu w całym kraju powoduje, że wymagania techniczne z praktycznych przyczyn sprowadza się do wspólnego mianownika bazy technicznej. Konsekwencją podzielenia zawodów na kwalifikacje jest zwiększenie liczby egzaminów.

Ponieważ egzamin służy przede wszystkim certyfikacji, informacje dostępne w raportach CKE, a nawet bardziej szczegółowych raportach OKE mogą być w ograniczonym stopniu wykorzystywane do oceny funkcjonowania systemu. Wyniki egzaminów nie dają całościowego obrazu rezultatów kształcenia zawodowego. Trudno jest przede wszystkim odnieść wyniki egzaminu do ogółu absolwentów. Skuteczność kształcenia zawodowego może być mierzona liczbą absolwentów, którzy decydują się na przystąpienie do egzaminu i uzyskują kwalifikacje zawodowe. Ale nawet w pierwszej fazie wdrażania systemu egzaminacyjnego, gdy do egzaminu przystępowali absolwenci, nie analizowano, a przynajmniej nie udostępniano informacji o tym, ilu spośród nich decydowało się przystępować do egzaminów. Częściowo jest to efekt niezintegrowania systemów informatycznych i niedofinansowania funkcji analitycznych w komisjach egzaminacyjnych. Wynika to też z braku wyraźnego podziału odpowiedzialności za jakość edukacji i jasnego zdefiniowania tej funkcji. W efekcie sprawozdania CKE i okręgowych komisji egzaminacyjnych dokumentują przebieg egzaminów i informują o liczbie zdających w określonej sesji egzaminacyjnej, co bez dodatkowych danych nie daje możliwości formułowania wniosków o jakości edukacji.

Egzamin potwierdzający kwalifikacje zawodowe jest kosztownym i ogromnym przedsięwzięciem logistycznym, wymagającym przygotowania setek arkuszy i zadań egzaminacyjnych, przeprowadzenia 
egzaminów (i ich ocenienia) dla sporej liczby osób, bo ponad 200 tys. rocznie. Wykorzystanie informacji wygenerowanych przez system egzaminacyjny schodzi na dalszy plan, zwłaszcza że wnioski musiałyby opierać się na danych z kilku sesji egzaminacyjnych (np. dla uczniów powtórnie przystępujących do egzaminu) lub uwzględniać inne dane z historii egzaminacyjnych zdających. Problemem jest też fragmentaryzacja systemu, przez co zdarza się, że egzamin jest przygotowywany dla kilku zdających. Dużo większe możliwości korzystania z danych egzaminacyjnych mają szkoły, które mogą skojarzyć dane egzaminacyjne z innymi informacjami dotyczącymi uczniów i absolwentów. Szkoły mogą wykorzystywać wyniki egzaminów zewnętrznych do poprawy jakości swojej pracy oraz korzystać z doświadczenia zatrudnionych nauczycieli posiadających uprawnienia egzaminatora, co jest często niedocenianą formą informacji zwrotnej dla systemu kształcenia zawodowego (Szmigel, Szaleniec 2017).

W zaproponowanych w 2018 r. zmianach przewidziano obowiązek przystąpienia do egzaminu przez wszystkich uczniów jako warunek ukończenia szkoły. Jak czytamy w uzasadnieniu tej zmiany w rządowym projekcie ustawy, „,wprowadzenie obowiązku przystąpienia do egzaminu zawodowego umożliwi uzyskanie - po raz pierwszy w historii szkolnictwa zawodowego - rzeczywistego obrazu jakości tego kształcenia" (druk sejmowy nr 2861, ocena skutków regulacji, s. 16). Praktyka funkcjonowania danych egzaminacyjnych w ostatnich kilkunastu latach pokazuje, że stanowią one ważną informację zwrotną, ale ich wykorzystanie wymaga rozbudowania funkcji analitycznych i lepszego powiązania systemów informatycznych, które umożliwiłyby ich przetworzenie na łatwe w interpretacji dla osób zainteresowanych wskaźniki oświatowe, wykorzystujące nie tylko dane z bieżącej sesji egzaminacyjnej, ale także z poprzednich prób podchodzenia do egzaminu i egzaminów z innych kwalifikacji. Takie spojrzenie na informacje egzaminacyjne jest istotne w sytuacjach, gdy uzyskanie dyplomu potwierdzającego kwalifikacje w zawodzie wymaga zdania egzaminu dla dwóch lub trzech kwalifikacji. Stanie się to też szczególnie ważne w analizach wyników uzyskiwanych przez absolwentów.

Podstawową miarą skutecznego realizowania przez egzamin funkcji certyfikacyjnej jest odsetek przystępujących do niego i zdających go osób oraz wykorzystanie potwierdzonych kwalifikacji na rynku pracy. Zwłaszcza w początkach funkcjonowania egzaminów wielu pracodaw- 
ców wręcz nie dostrzegło wprowadzonej zmiany. Z czasem świadomość istnienia egzaminów i ich wartości informacyjnej wzrosła, ale wciąż wielu pracodawców utożsamia świadectwo ukończenia szkoły z potwierdzeniem uzyskania kwalifikacji niezbędnych do wykonywania danego zawodu. Nie zwiększyło się także zainteresowanie uczniów egzaminem. Wyniki zdawalności egzaminu potwierdzającego kwalifikacje zawodowe na poziomie $76 \%$ dotyczą jedynie osób przystępujących do niego. Brakuje wiarygodnych danych, ale do egzaminu nie podchodzi ok. 1/3-1/4 uczniów, najmniej w technikach i szkołach policealnych, więcej w zasadniczych szkołach zawodowych. Jest to głównie efekt braku zainteresowania uczniów egzaminem (Pfeiffer 2015). W niektórych zawodach do egzaminu przystępuje mniej niż połowa uczniów. Autorzy rządowego projektu ustawy o kształceniu zawodowym podają przykład techników informatyków, którym w latach 2012-2017 okręgowe komisje wydały zaledwie 19,1 tys. dyplomów przy rocznej liczbie absolwentów sięgającej 95 tys., czy techników mechatroników, gdzie analogiczna relacja wynosiła 4,5 tys. do 20 tys. W połączeniu z relatywnie niską zdawalnością oznacza to, że na rynku pracy jedynie mniejszość absolwentów posiada potwierdzone kwalifikacje lub potwierdza je w inny sposób. Sytuacja w poszczególnych kwalifikacjach i zawodach szkolnych jest bardzo zróżnicowana i wymaga bardziej pogłębionych analiz, których bardzo brakuje w polskiej literaturze dotyczącej kształcenia zawodowego. Małe zainteresowanie uczniów potwierdzaniem kwalifikacji może też świadczyć o ich przekonaniu o niskiej wartości rynkowej dyplomów.

Fundamentalnym problemem systemu egzaminów zawodowych jest nieprecyzyjne zdefiniowanie ich funkcji. Szczególnie widoczne jest oczekiwanie, że egzaminy będą pełnić funkcję zarówno certyfikacyjną, jak i ewaluacyjno-kontrolną, i tu można doszukiwać się słabości istniejącego systemu. Najpierw należałoby jasno określić, jakiemu celowi egzaminy mają służyć. Potem zaś należy się zastanowić, jak ten cel rozsądnie zrealizować. Jeśli egzaminy mają głównie pełnić funkcję certyfikacyjną, to podaje to w wątpliwość potrzebę centralizacji i ich jednolitości. W dyskusjach i propozycjach rozwiązań często wskazuje się na potrzebę większego zaangażowania pracodawców na różnych etapach przygotowywania i przeprowadzania egzaminów. W celu zwiększenia trafności i wiarygodności egzaminów pożądane byłoby zaangażowanie pracodawców zwłaszcza w ich projektowanie i przeprowadzanie, tak 
jak jest w najlepiej funkcjonujących systemach kształcenia zawodowego. W sugerowanych rozwiązaniach pojawiają się także propozycje umożliwienia przedsiębiorstwom organizacji egzaminów. Wprowadzenie tego typu rozwiązań wymagałoby uelastycznienia istniejącego systemu i zmniejszenia liczby certyfikowanych kwalifikacji. Podobnie jak w przypadku walidacji w zintegrowanym systemie kwalifikacji, umożliwiłoby to włączanie do procesu certyfikacji dowodów z bardziej różnorodnych i mniej standaryzowanych form oceniania.

W celu wzmocnienia funkcji ewaluacyjno-kontrolnych i monitorujących warto wypracowywać uzupełniające instrumenty mierzenia jakości kształcenia zawodowego, np. pogłębione badania umiejętności zawodowych i ogólnych uczniów i absolwentów czy opinie pracodawców. Ważna jest także kwestia relacji między ocenianiem wewnątrzszkolnym i zewnętrznym. W obecnym systemie uwaga skupia się głównie na egzaminach zewnętrznych, traktując je jako ważne i, jak można czasem odnieść wrażenie, jedyne wiarygodne źródło informacji o wiedzy i umiejętnościach uczniów i absolwentów. Wykorzystanie dodatkowych źródeł danych o jakości kształcenia i umiejętnościach uczniów i absolwentów jest ważne także do poprawy jakości samych egzaminów i budowania zaufania do systemu kształcenia zawodowego. 